\title{
Ore Mineralogy of High Sulfidation Çorak-Taç Epimesothermal Gold Deposit (Yusufeli-Artvin-Turkey)
}

\author{
K. Diarra ${ }^{1}$, E. Sangu ${ }^{1}$, and E. Çiftçi ${ }^{2(\bowtie)}$ \\ ${ }^{1}$ Department of Geological Engineering, Faculty of Engineering, \\ KOU, 41380 Kocaeli, Turkey \\ 2 Department of Geological Engineering, Faculty of Mines, \\ ITU, 33469 Maslak, Istanbul, Turkey \\ eciftci@itu.edu.tr
}

\begin{abstract}
Taç, two nearby mineralizations, are located in the eastern black sea region, which is one of the most productive metallogenic belts of Turkey. It is characterized by a great number of Kuroko-type volcanogenic massive sulfide deposits as well as vein-type polymetallic deposits, porphyry and epithermal precious metal deposits. Subject neighboring deposits are hosted within the voluminous Cretaceous-Eocene granitoids and interbedded volcanic rocks and carbonates. Mineralogy of altered host rocks include quartz veins, carbonates, sericite, chlorite, chalcedony, and disseminated sulfides - mainly pyrite, sphalerite, galena, and chalcopyrite. The main texture encountered in the host rocks is hyaloporphyry. Due to hydrothermal alterations primary minerals are mostly altered in which the ferromagnesian minerals are chloritized and calcified, while feldspars are altered into sericite, calcite, and albite. Silicification and argillic alteration (medium, moderate, high) are widely spread however; XRD analysis carried on 33 core samples from Çorak has also revealed local propylitic alteration, limonitization and hematitization as well. The minerals assemblages that accompanied the different alterations include jarosite and alunite suggesting high sulfidation hydrothermal mineralization. Through the ore microscopic studies, pyrite, chalcopyrite galena, sphalerite, and a lesser amount of sulfosalts (tennantitetetrahedrite and pyrargyrite) were determined. Quartz and calcite account for the main gangue minerals. While the Taç mineralization is pyrite, chalcopyrite and sphalerite dominating, the Çorak mineralization contains relatively less chalcopyrite and galena becomes prevalent with sphalerite. Gold in both sites may reach up to $10 \mathrm{ppm}$, on average $3 \mathrm{ppm}$. Silver occurrence is insignificant.
\end{abstract}

Keywords: Yusufeli $\cdot$ Artvin $\cdot$ Turkey $\cdot$ High sulfidation $\cdot$ Gold $\cdot$ Epimesotherma

\section{Introduction}

The study area is located in Yusufeli area in the eastern Pontides' northeastern most tip within a larger metal rich tectonic corridor stretching from southern Georgia and northern Armenia to Bulgaria and Romania and it is a host to numerous volcanogenic massive sulfide (VMS) and vein-type deposits dominantly of Late Cretaceous age. 
Taç and Çorak deposits occur in an area about $10 \mathrm{~km} \times 3 \mathrm{~km}$ in size, oriented NW-SE and SW-NW, respectively. It is limited to the north by series of outcrop of large unaltered basaltic basement with some andesite enclave. They are covered by more recent tuffs, sandstone and old alluvial fan. The south is more dominated by andesites and tuff outcrops together with relatively recent sedimentary covers.

Mineralization and alteration are represented by extensive strata-bound argillic alteration cut by gold and base metal bearing quartz veins within a massive pyroclastic volcanic host-rock below a bedded volcanogenic succession, with additional receptive massive volcanic units occurring higher up in the sedimentary succession. Porosity is believed to be the most likely control on the stratiform nature of alteration. However, proximity to major structures along or close to the structural axis appears to be an important influence on the presence of alteration suggesting structural control on mineralization.

Some typical structures are associated with the $\mathrm{Cu}-\mathrm{Pb}-\mathrm{Zn}$ mineralization: The most obvious one is the hydrothermal alteration with its colored intense argillic and propylitic alterations. They are always associated with a local fault. Afterward, the large intrusive rocks are crosscutting the volcanic, the pyroclastic and the volcano sedimentary rocks.

In Çorak SW-NE section view, the high grade of base metal representing the mineralization is localized in volcano sedimentary rock (tuff) as well as in andesite and feldspar porphyry andesitic, the three sets are separated by set of faults.

\section{Methods and Approaches}

For mineralogical and ore microscopy studies, 35 thin and polish sections from core drill and outcrop, have been prepared and scrutinized under reflect and transmitted light microscope of the laboratories of Kocaeli university (KOÜ) and Istanbul technical university (ITU) in Turkey. 6 samples have been taken from alteration zone have been analysis in order to compute their CIA: $\left(\left[\mathrm{Al}_{2} \mathrm{O}_{3} /\left(\mathrm{Al}_{2} \mathrm{O}_{3}+\mathrm{CaO}+\mathrm{K}_{2} \mathrm{O}+\mathrm{Na}_{2} \mathrm{O}\right)\right]\right.$ 100) and ICV: (ICV: $\mathrm{CaO}+\mathrm{K}_{2} \mathrm{O}+\mathrm{Na}_{2} \mathrm{O}+\mathrm{Fe}_{2} \mathrm{O}_{3}$ (t) $+\mathrm{MgO}+\mathrm{MnO}+\mathrm{TiO}_{2}$ )/ $\mathrm{Al}_{2} \mathrm{O}_{3}$ ). The target was to determine their depositional environment as well as the alteration styles. 33 samples from different alteration zones from Çorak have been submitted to the lithological and XRD analysis using Rietveld methods.

15 polished thin sections have been subjected to Cathodoluminescence (CL) microscopy study to describe and to distinguish gangue minerals and minerals generations. Samples containing mostly sphalerite, quartz and carbonates were chosen, since they are able to produce CL emissions. The CL study was performed at the ITU Advanced Microscope lab using an optical cathodoluminescence system (CITL MK5 system). 


\section{Results and Discussion}

The andesite and andesitic tuffs are the main lithologies hosting the mineralization in the study area. The mineralogy of the altered hostrock enclosed quartz veins, carbonate, sericite, chlorite, and chalcedony and disseminated sulfides. Their details microscopic studies have revealed the following common textures: trachytic; hyalo microlithic porphyry; vesicular microlithic porphyry; hyalo micro granular porphyry and quasioolithic. The hydrothermal alteration manifest itself in the form of silicification, epidotization, chloritization, seritization, and finally a calcification as a last stage. Colored argillic alteration is widespread in the area along with silicic and propylitic alteration. Drill holes intercept sulfide ore zones at different depth. The sulfide mineralizations may range from $50 \mathrm{~cm}$ to $1 \mathrm{~m}$ in thickness. Weakly mineralized zones of 1 to $2 \%$ with disseminated sulfides are intercalated between the massive or semi massive sulfide lenses. The altered interval shows 3 types of minerals assemblages: Quartz + sericite + calcite, quartz + epidote and quartz + chlorite + calcite: (I) quartz + chlorite alteration: In this facies, the ferromagnesian (Amphibole) are completely chloritized and calcified. Chlorites are filling cavity as well. They wrap also the fewer amount of chalcedony present in the groundmass. The opaque minerals represent less than $1-2 \%$ of the groundmass. The texture is vesicular hyalo-microlithic porphyry; (II) quartz + epidote alteration: In this facies, the light colored plagioclases are turned into epidote. The calcite as a last phase is filling fracture. (propylitic alteration); (III) quartz + sericite alteration: The sericite is not only replacing the ferromagnesian and the plagioclase but also the matrix. Plagioclases turned into sericite. Euhedral quartz is present in the groundmass. The most prevalent ore mineral in Çorak is pyrite it is present in all the samples. It is followed by chalcopyrite, sphalerite, and galena. Compare to sulfides, sulfosalts namely tennantite-tetrahedrite are present in lesser amounts. Covellite and bornite are rare. Gangue minerals are mainly composed of quartz and calcite. Two main mineral's assemblages are prevailing whether it is from stockwork (disseminate and veinlet zone) or from the high grade sulfide zone. In the stockwork zone pyrite has euhedral to subhedral shape. Chalcopyrite is anhedral and replaces very often pyrite. In the massive ore zone, pyrite and chalcopyrite are accompanied by large sphalerite and galena grain. Galena always crosscut sphalerite, suggesting that it is later than sphalerite. Tennantite and tetrahedrite assemblage replace very often pyrite and chalcopyrite in this zone. The pyrargyrite is present in very small amount. The tennantite is dominant in Çorak's polymetallic sulfide zone. It has been also observed galena replacing gangue minerals quartz suggesting symplectic intergrowths of ore minerals with silicate. Colloform texture is observed but they are rare. Except the pyrite, all the minerals are anhedral. Minerals size span from 50 to 300 micron. The sulfosalts are the smallest ones (Figs. 1a-f). 


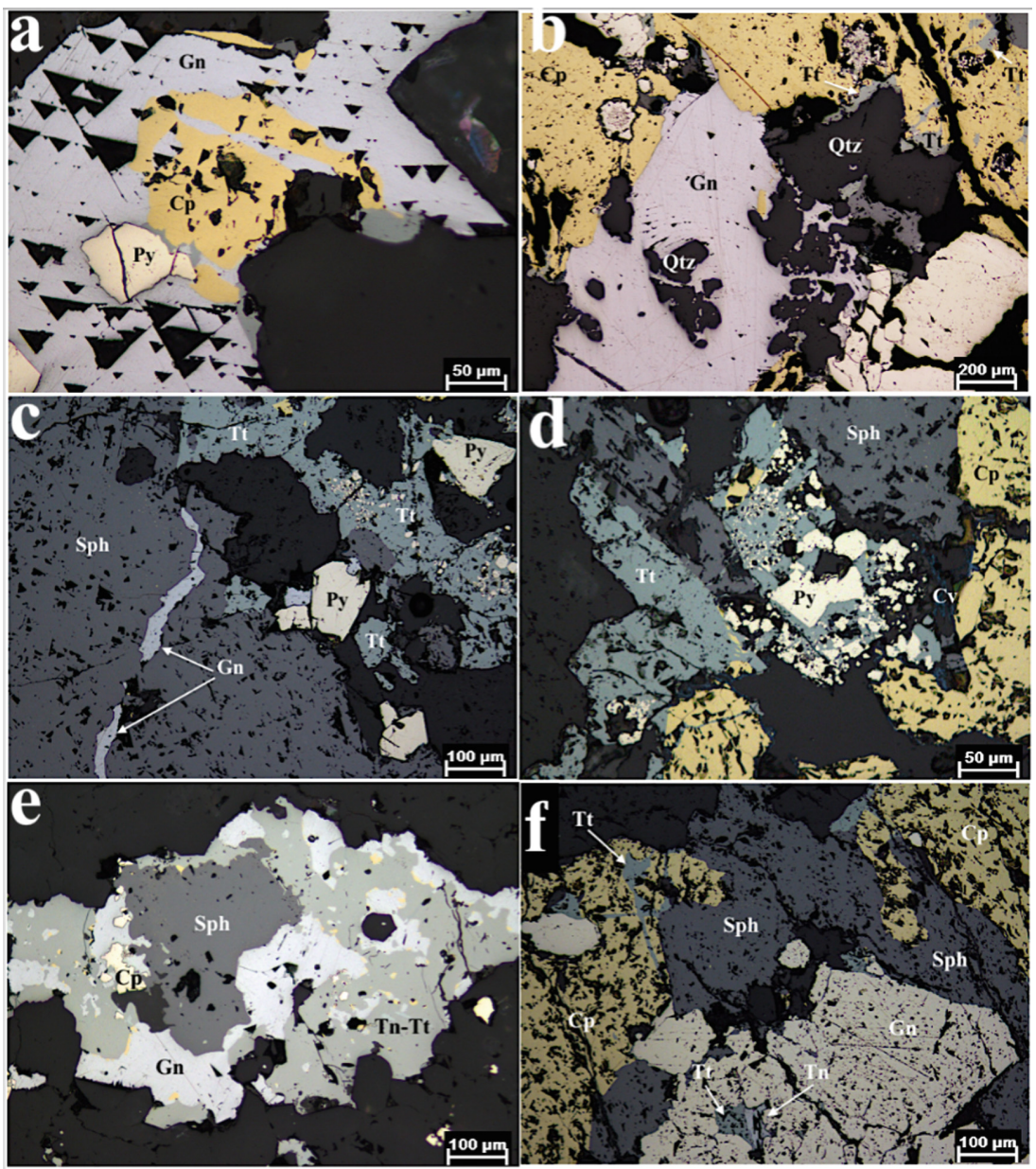

Fig. 1. (a) galena replacing chalcopyrite; (b) galena replacing quartz, replacement of gang minerals by ore minerals (symplectic intergrowths) and tennantite replacing chalcopyrite; (c) galena veins sphalerite, while pyrite replaced by tennantite; (d) tennantite replacing pyrite and chalcopyrite; (e) tetrahedrite veining galena and tetrahedrite-tennantite replacing sphalerite (Py: galena; Cp: chalcopyrite; Sph: sphalerite; Tn-Tt: Tennantite-Tetrahedrite; Qtz quartz)

The following paragenesis is deducted from the ore microscopy study: Pyrite Chalcopyrite (I) - Sphalerite - Galena - Sulfosalts- Chalcopyrite (II) - Bornite Covellite.

The cathodoluminescence study on sphalerite has revealed heterogeneity in the composition of the sphalerite (Fig. 2). These states that those sphalerite grains are originated from more than one generation phase and/or from fluids with changing composition. 


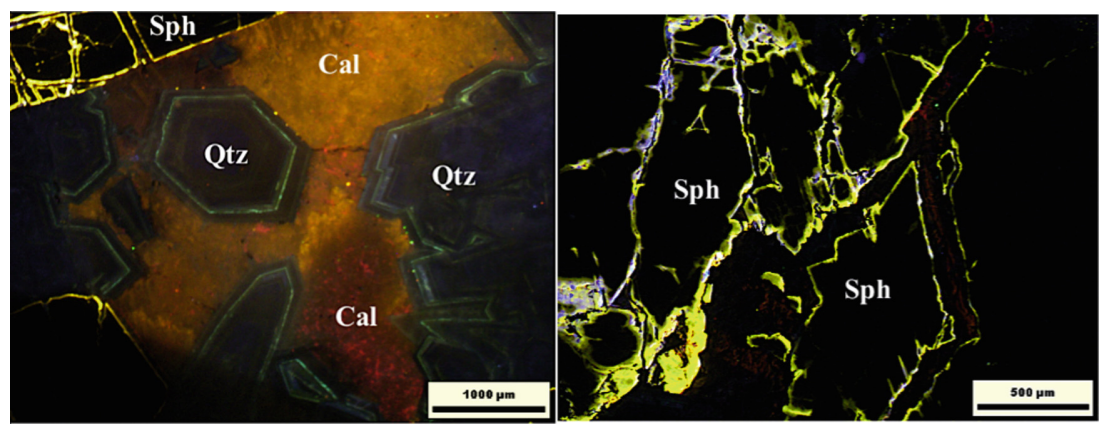

Fig. 2. Optical cathodoluminescence microscopy images (OCLMI) of sphalerite and quartz grains with infilling late calcite, showing compositionally heterogeneity sphalerites

\section{Conclusions}

Taç and Çorak deposits occur in north easternmost tip of the eastern Pontides tectonic belt of Turkey. They are two separate ore bodies within the same system. Hydrothermal alteration is intense and extensive in the form of silicification, epidotization, chloritization, seritization, and finally a calcification as the final stage. Three main alterations zone are succeeding from the proximal, intermediate to distal zone: Quartz + Chlorite alteration, quartz + epidote alteration, quartz + sericite alteration. Two main mineral's assemblages are prevailing whether it is from stockwork (disseminated and veinlet) or from the high grade sulfide zone. They are respectively: pervasive pyrite, chalcopyrite with sphalerite and galena.

Argillic, propylitic and silicic alteration induced by acidic hydrothermal fluids have led to the formation of quartz, muscovite, orthoclase, gypsum, dolomite, kaolinite, pyrite, sphalerite, galena and the pair jarosite-alunite assemblage. The presence of alunite and jarosite minerals indicate that Çorak and Taç are high sulfidation epithermal deposit with mesothermal signatures.

Acknowledgements. This study was financially supported by BAP Project unit (No: 2017/80) of Kocaeli University in Turkey. We are thankful to the university and to Santral Mining Co. and their employees in Yusufeli for their courteous support for the field work.

\section{References}

1. Bogdanov B (1980) Massive sulphide and porphyry copper deposits in the Panagjurishte district, Bulgaria. In: Jankovic S, Sillitoe Richard H (eds) European copper deposits; Proceedings of an international symposium. Springer, Berlin-Heidelberg-New York, pp 50-58

2. Ciftci E (2000) Mineralogy, paragenetic sequence, geochemistry, and genesis of the gold and silver bearing upper cretaceous mineral deposits, Northeastern Turkey. PhD dissertation, University of Missouri-Rolla, Missouri, USA, p 251 
3. Kouzmanov K, Moritz R (2009) Late Cretaceous Porphyry $\mathrm{Cu}$ and epithermal $\mathrm{Cu}-\mathrm{Au}$ association in the Southern Panagyurishte District, Bulgaria: The paired Vlaykov Vruh and Elshitsa deposits

4. Muntean JL, Einaudi MT (2000) Porphyry gold deposits of the Refugio district, Maricunga belt, Northern Chile. Econ Geol 95:1445-1472

Open Access This chapter is licensed under the terms of the Creative Commons Attribution 4.0 International License (http://creativecommons.org/licenses/by/4.0/), which permits use, sharing, adaptation, distribution and reproduction in any medium or format, as long as you give appropriate credit to the original author(s) and the source, provide a link to the Creative Commons license and indicate if changes were made.

The images or other third party material in this chapter are included in the chapter's Creative Commons license, unless indicated otherwise in a credit line to the material. If material is not included in the chapter's Creative Commons license and your intended use is not permitted by statutory regulation or exceeds the permitted use, you will need to obtain permission directly from the copyright holder. 